\title{
Branding yang Dilakukan Humas pada Perguruan Tinggi Swasta
}

\author{
Yugih Setyanto'; Paula T. Anggarina ${ }^{2}$; Anny Valentina ${ }^{3}$ \\ ${ }^{1}$ Fakultas Ilmu Komunikasi, Universitas Tarumanagara \\ yugihs@fikom.untar.ac.id \\ ${ }^{2}$ Fakultas Ekonomi, Universitas Tarumanagara \\ Paula.anggarina@gmail.com \\ ${ }^{3}$ Fakultas Seni Rupa dan Disain, Universitas Tarumanagara \\ annyv@,fsrd.untar.ac.id
}

\begin{abstract}
ABSTRAK
Branding sering diidentikkan dengan keberadaan sebuah institusi bisnis yang berorientasi profit. Namun dalam perkembangannya sudah banyak institusi non profit seperti organisasi pemerintah, LSM dan lembaga pendidikan seperti perguruan tinggi merasa perlu melakukan upaya branding. Dalam upaya melakukan branding, humas sebagai sebuah unit kerja yang berada di lembaga perguruan tinggi juga sering mendukung upaya ini. Hal ini menandakan bahwa perguruan tinggi pun memiliki kesadaran bahwa branding dan keberadaan humas bukanlah sekedar trend namun didasari pada kebutuhan pentingnya sebuah identitas yang dapat menunjukkan eksistensi perguruan tinggi di mata masyarakat. Namun pesatnya pertumbuhan perguruan tinggi swasta juga berdampak adanya persaingan dalam menarik calon mahasiswa. Untuk menarik calon mahasiswa ini perguruan tinggi swasta menggunakan cara-cara diantaranya dengan melakukan komunikasi yang intensif serta mengedepankan identitas perguruan tinggi agar lebih dikenal oleh masyarakat. Brand sebuah perguruan tinggi menjadi salah satu identitas institusi yang dikedepankan. Penelitian ini menggunakan pendekatan kualitatif dengan teknik pengumpulan data melalui wawancara, observasi dan studi literatur. Penelitian ini akan melihat dari sudut pandang ilmu komunikasi yang menganalisis berbagai aspek yang dilakukan Humas dalam mendukung branding termasuk manajemen humas yang mengelolanya. Kesimpulan yang didapat adalah branding pada perguruan tinggi swasta perlu dilakukan dalam rangka memperkuat reputasi. Reputasi harus dibentuk melalui kinerja yang baik. Humas berperan dalam upaya branding tersebut.
\end{abstract}

Kata kunci: humas, branding, perguruan tinggi swasta

\section{Pendahuluan}

Kegiatan public relations atau hubungan masyarakat (humas) yang dikonseptualisasi dan operasionalisasi oleh sebuah organisasi, meskipun pada hakikatnya mempunyai persamaan, dalam hal tertentu memiliki perbedaan-perbedaan disebabkan oleh jenis organisasinya yang memang berbeda (Sunarto, 2012, h. 4).

Bagaimana dengan organisasi perguruan tinggi? Inilah yang menjadi pembeda bila dibanding dengan dua jenis organsiasi tadi (profit dan non profit). Organisasi perguruan tinggi perlu ditempatkan di posisi tersendiri. Perguruan tinggi adalah lembaga pendidikan dimana karakternya tidak persisi sama dengan dua organisasi tadi.

Perguruan tinggi khususnya swasta mempunyai fungsi pendidikan yang jauh dari komersialisasi. Namun agar perguruan tinggi swasta bisa terus "hidup" tentulah harus dikelola layaknya sebuah perusahaan. Perguruan tinggi dituntut seakan berjalan meniti ditengah garis batas- tidak boleh komersil namun harus menghasilkan. Inilah istimewanya sebuah lembaga pendidikan. Sayangnya di era global yang penuh kompetisi ini perguruan tinggi swasta seakan terbawa arus komersialisasi yang sedikit melupakan fungsi pendidikannya. Tentu, Humas yang melekat pada sebuah organisasi juga mempunyai peran yang menyesuaikan jenis organisasinya. 
Salah satu upaya yang saat ini dilakukan berbagai perguruan tinggi dalam mempromosikan kampusnya adalah dengan melakukan branding. Upaya ini diketengahkan untuk dapat memperkuat promosi serta pengenalan perguruan tinggi kepada masyarakat khususnya sasaran yang dituju. Dalam perkembangannya brand sebagai, identitas perguruan tinggi menjadi alat yang dilakukan untuk mendukung promosi. Sementara itu unsur branding itu sendiri sangat terkait dengan disain yang dapat menumbuhkan persepsi mengenai citra institusi di benak publik. Dalam brand terdapat pesan yang menggambarkan identitas institusi untuk diketahui oleh masyarakat. Berdasarkan latar belakang tersebut maka rumusan masalah penelitian ini adalah bagaimana branding yang dilakukan humas pada perguruan tinggi swasta.

\section{Landasan Teori}

Humas dalam makna yang sederhana disampaikan Simon dalam Tamin (2012) dapat diartikan sebagai melakukan hal yang baik dan memberi tahu masyarakat tentang hal tersebut. Dari penjelasan singkat ini dapat dipahami bagaimana Humas bekerja yaitu menyampaikan kepada masyarakat akan hal baik yang telah kita lakukan. Di sini terkandung pengertian bahwa masyarakat patut mendapatkan informasi mengenai organisasi dan sebaliknya organisasi pun harus memberitahukannya.

Menurut Lesly (dalam Sunarto, 2012) ada beberapa aspek yang dilakukan humas dan diantaranya adalah memberikan citra yang baik sebagai tujuan akhir. Disamping itu juga mempromosikan produk atau jasa. Melalui penelitian ini, akan melihat sebuah brand perguruan tinggi memberikan citra yang positif skaligus mendorong usaha promosi yang dilakukan humas.

Para ahli juga berpendapat bahwa humas juga memiliki fungsi manajemen. Heath dan Coombs (2006) dalam bukunya Today's Public Relations An Introduction menulis:

"Public relations is the management function that entails planning, research, publicity, promotion, and collborative decision making to help any organization's ability to listen to appreciate, and respond appropriately to those persons and groups whose mutually beneficial relationships to organization needs to foster as it strives to achieve its mission dan vision".

Dari berbagai definisi tentang humas kemudian dapat diambil lima karakter kunci dari humas disampaikan Heath dan Coombs (1) A management function (2) the five major functions of public relations (3) the practitioner's need to listen, appreciate, and respond (4) the emphasis on mutually beneficial relationship and (5) the achievement of a particular mission and vision. Peran dan fungsi humas dapat diwujudkan dalam program kegiatan kehumasan yang telah dirancang sebelumnya dengan strategi yang tepat agar program dapat berjalan dengan baik.

Strategi humas adalah manajemen hubungan antara organisasi dan khalayak atau stakeholder yang bervariasi dengan skala prioritas yang berbeda dari waktu ke waktu. Pertumbuhan ekonomi makro dan mikro, serta studi manajemen lingkungan telah menambah penekanan pada ranah humas dalam dimensi organisasi yang lebih dari sekedar memperoleh keuntungan dan untuk memasukkan tanggung jawab sosial sebagai salah satu ukuran kesuksesan korporat. Kegiatan humas berperan penting bagi kebijakan organisasi berkaitan dengan faktor-faktor lingkungan yang mempengaruhi aktivitas bisnis perusahaan. Faktor-faktor ini termasuk stratifikasi sosial, kesejahteraan sosial, serta proses-proses politik, hukum, dan peraturan yang berhubungan dengan operasi perusahaan. Semua 
faktor ini perlu dipahami karena dapat mempengaruhi reputasi organisasi dan penerimaan publik (Oliver, 2007, h.13).

Perencanaan strategis dalam humas melibatkan pengambilan keputusan tentang tujuan dan sasaran program, pengenalan publik utama, penetapan kebijakan atau aturan untuk menjadi pedoman pemilihan strategi, dan penentuan strategi. Harus ada hubungan yang dekat antara keseluruhan tujuan program, sasaran untuk ditetapkan bagi setiap publik, dan strategi untuk dipilih. Kuncinya adalah bahwa strategi dipilih untuk mewujudkan hasil tertentu. Praktisi PR bekerja sama dengan manajer-manajer lain untuk mengembangkan rencana program strategis (Cutlip, 2005, h. 295).

Sementara itu, khusus dalam menyoroti humas perguruan tinggi Nasution (2006) menyampaikan fungsi penting lainnya yang harus dilakukan humas perguruan tinggi ada dua hal, yakni :

a.Fungsi membangun (konstruktif), dalam hal ini perguruan tinggi dapat membagi pada aspek keilmuan sebagai alat memecahkan masalah yang dapat diterima masyarakat, dan kebijakan perguruan tinggi bisa diterima segenap civitas akademika.

b.Fungsi korektif, dimana Humas harus mampu menetralisir setiap opini negatif yang berkembang di masyarakat internal maupun eksternal. Fungsi korektif ini berusaha agar perguruan tinggi tidak melakukan sesuatu yang bisa merugikan organisasi. Selain itu juga memberikan input yang diperlukan dalam mengambil kebijakan.

Perguruan tinggi juga mempunyai stakeholder eksternal yang tidak kalah berperannya layaknya di dunia usaha. Perguruan tinggi wajib berelasi dengan pemerintah khususnya Kemendikti dan riset karena terkait dengan banyak kebijakan dan aturan. Dunia usaha juga mitra yang sangat startegis bagi perguruan tinggi. Kerja sama dengan dunia usaha dapat menjadi bukti kepercayaan akan krdibilitas perguruan tinggi terhadap mutu lulusan dan produk-produk ilmiah dari hasil penelitian yang dapat dimanfaatkan dunia usaha. Dan tentu saja media. Semestinya media juga merupakan relasi penting perguruan tinggi. Media dan perguruan tinggi adalah dua institusi yang mempunyai tujuan memberi pencerahan bagi masyarakat.

Humas di perguruan tinggi mempunyai tugas dan fungsi yang harus menitikberatkan pada fungsi sosial sebagai sebuah lembaga pendidikan namun juga harus memberi profit kepada institusi. Dengan semakin banyaknya perguruan tinggi swasta saat ini semakin membuat pelayanan untuk memberikan pendidikan yang terbaik semakin kompetitif. Tidak bisa dipungkiri bahwa setiap tahun peguruan tinggi "bersaing" untuk mendapatkan mahasiswa baru. Keadaan seperti ini tentu melibatkan upaya promosi, marketing dan tentu saja Humas.

Sementara itu untuk penjelasan yang lebih khusus terkait humas pada perguruan tinggi dapat dijelaskan dalam definisi yang disampaikan oleh Lumbald dan Stewart $(2005$, h. 4) bahwa School community relations (school PR) is a planned process of two ways communication between a school and its publics directed toward school improvement. Disamping itu juga dijelaskan beberapa tujuan yang akan dihasilkan dari humas diantaranya adalah meningkatkan pemahaman dan mempengaruhi perilaku khalayak (Lumbald \& Stewart, 2005, h. 3). Dari dua tujuan Humas di atas dapat dikaitkan dengan makalah ini bahwa peguruan tinggi punya tujuan yang dapat memberikan pengetahuan, pemahaman bahkan pencerahan dan hal tersebut menjadi penekanan tujuan humas di perguruan tinggi. 
Pemahaman mengenai brand didefinsikan Philips Kotler dalam Rangkuti (2008:35) adalah: A brand name, term, sign, symbol, or design or combination of them, inteded to identify the goods or services of one seller of groups of sellers and differentiate them from those competitors.

Sedangkan menurut AB Susanto dan Himawan Wijanarko (2004, h. 6) menjelaskan merek adalah nama atau simbol yang diasosiakan dengan produk atau jasa dan menimbulkan arti psikologis atau asosiasi. Sementara konsultan brand Amalia Maulana menyebutkan brand adalah merek yang dimiliki oleh perusahaan. Amalia juga menjelaskan mengenai branding yaitu kumpulan kegiatan komunikasi yang dilakukan oleh perusahaan dalam rangka proses membangun dan membesarkan brand. Tanpa dilakukannya kegiatan komunikasi kepada konsumen yang disusun dan direncanakan dengan baik, maka sebuah merek tidak akan dikenal dan tidak mempunyai arti apa-apa bagi konsumen atau target konsumennya (Maulana, 2010).

Sementara itu Michael Levine (2013, h.12) mengemukakan hubungan antara humas dalam branding. Menurutnya, "Public relations does not create the product or its identity. Its role in branding is considerably more subtle". Terkait branding, public relations tidaklah menciptakan produk atau identitasnya. Peran humas jauh lebih "halus". Humas membuat identitas produk dikomunikasikan kepada khalayak. Lanjutnya : Public relations is about message and their delivery, but the isn't all public relations is in correlation with branding, the goal of public relations must always be to create a feeling in the mind of target audience for which the message is being tailored. If branding is about creating an identity for product, service, or etentity (company or individual). Public relations contribution to branding, is about making that identity friendly and likeable for the public-specifically the public for which the message is intended (Lenvine, 2003, h. 1).

Lenvine beranggapan bahwa kontribusi humas dalam branding adalah membuat identitas menjadi lebih dekat terutama bagi khalayak dimana pesan disampaikan.

\section{METODE PENELITIAN}

Pendekatan yang digunakan dalam penelitian ini adalah pendekatan kualitatif karena peneliti melakukan penelitian langsung secara intensif, terinci dan mendalam terhadap suatu organisasi, lembaga atau gejala tertentu serta dengan pengamatan obyek (kegiatan atau peristiwa) yang diteliti secara mendalam. Dalam penelitian ini mencoba mendeskripsikan secara sistematis, faktual, dan akurat mengenai Branding yang dilakukan Humas khususnya di perguruan tinggi. Hal ini dilakukan dengan melakukan pengamatan dan melalui jawaban-jawaban pertanyaan yang diajukan kepada informan.

Nara sumber yang akan diwawancara dalam penelitian ini adalah ahli humas dan branding yang memahami kedua bidang ini secara akademik dan memiliki pengetahuan yang mendalam secara kelimuan yaitu Pakar Kehumasan Prayudi., Ph.D dan Asesor Profesi Kehumasan yang juga dosen humas di program studi ilmu komunikasi Universitas Atma Jaya Yogyakarta. Sedangkan sebagai informan adalah Kahumas KKGS (perguruan tinggi swasta di Jakarta) Gita (bukan nama sebenarnya), Kahumas Unika Atma Jaya Jakarta Lisa Esti Puji Hartanti, S.Sos., M.Si dan Kahumas Universitas Islam Sultan Agung Semarang Trimanah M.Si. Sedangkan untuk informan dari praktisi agar penelitian ini dapat melihat dari sisi branding adalah Herwindo- seorang sarjana disain dan saat ini menjadi praktisi pada bisnis disain grafis. 


\section{PEMBAHASAN}

Perguruan tinggi khususnya swasta mempunyai fungsi pendidikan yang jauh dari komersialisasi. Namun agar perguruan tinggi swasta bisa terus "hidup" tentulah harus dikelola layaknya sebuah perusahaan. Muktiyo dikutip Sinatra dan Darmastuti dalam Jurnal Ilmu Scriptura (2008) menyatakan: "PTS-PTS yang dituntut untuk dapat swadana dan swakelola ini masih dibebani dengan mempertimbangkan moral, etika, dan status yang sarat dengan tuntutan. Artinya, kiprah bisnis perguruan tinggi tentu saja tidak sedemikian bebasnya seperti sosok perusahaan manufaktur atau industri jasa lainnya”.

Pengamat Kehumasan Prayudi, Ph.D mengatakan bahwa perguruan tinggi swasta membawa misi sosial namun sebagai sebuah institusi swasta rasanya tidak mungkin bila perguruan tinggi swasta tidak memikirkan faktor profit. Menurutnya perguruan tinggi swasta tetap dituntut untuk menghasilkan profit. Menurut Prayudi, "Kalau kita bicara perguruan tinggi swasta maka sebenarnya kalo perguruan tinggi swasta dilihat dari industrinya maka dia industri di bidang jasa pendidikan. So, buat saya itu menjadi hal yg sah karna pembiayaan, BOPT, biaya operasional Perguruan tinggi, mostly berdasarkan uang kuliah yang dibayarkan oleh mahasiswa".

Pendapat ini memperjelas posisi perguruan tinggi swasta yang memiliki fungsi sosial namun eksistensi dan keberlanjutan sebagai sebuah organisasi harus tetap ada. Hal inilah yang membuat perguruan tinggi swasta harus mencari upaya bisnis untuk berjalan.

Disampaikan lagi oleh Sinatra dan Damayanti bahwa perguruan tinggi bukan lagi lembaga non profi yang "hanya" bergerak dalam bidang ilmu dan "transfer of knowledge". Lebih dari itu, perguruan tinggi menjadi lembaga profit dengan topeng "transfer of knowledge" dan ilmu menjadi produk yang dijualbelikan. Sinatra dan Damayanti menilai dalam kaitannya dengan citra perguruan tinggi di mata konsumen, bahwa dalam tatanan ini citra sebuah perguruan tinggi menjadi satu hal yang penting dan menjadi satu pertimbangan konsumen ketika mereka memutuskan perguruan tinggi mana yang akan dipilih (http://scriptura.petra.ac.id/index.php/iko/article/view/16943/16929).

Setelah diketahui arah dari perguruan tinggi swasta maka hal ini pun memberi pengaruh pada Humas yang ada di dalamnya. Dampaknya menurut Prayudi - aktivitas Humas pun juga di satu sisi harus menjalankan tridharma perguruan tinggi sebagai sebuah kewajiban perguruan dimanapun namun di sisi lain juga harus berpikir komersil. Contohnya adalah ada perguruan tinggi yang meminta Humasnya untuk melakukan branding agar brand perguruan tingginya semakin kuat.

Gita (bukan nama sebenarnya) yang menjabat Kepala Humas sebuah perguruan tinggi swasta sebut saja KKGS - di Jakarta Utara merasa keberadaan Humas di perguruan tinggi swasta sangat penting. Menurutnya perguruan tinggi adalah pusat dari ilmu pengetahuan, maka kegiatan Humas pada peguruan tinggi diharapkan salah satu fokusnya adalah pada pusat pemberdayaan masyarakat.

Hal senada juga disampaikan Lisa Esti Puji Hartanti, S.Sos., M.Si yang menjabat Humas Unika Atma Jaya Jakarta menyatakan bahwa Humas mutlak ada dalam sebuah institusi. Khusus Humas di perguruan tinggi swasta, menurutnya wajib dimiliki oleh institusi perguruna tinggi. Lisa mengatakan, "Dikarenakan, PT (perguruan tinggi) pun perlu membangun branding dan reputasi. Ditambah, PT menawarkan jasa yang menuntut kualitas dan membangun kepercayaan dari customernya". 
Dari kedua pendapat praktisi yang menjalankan Humas di perguruan tingginya masing-masing tampak bahwa Humas menjadi sebuah unit yang wajib ada pada perguruan tinggi saat ini. Kedua alasan yang diutarakan dapat menjadi catatan akan semakin meluasnya fungsi Humas yang selama ini hanya dikaitkan dengan perusahaan atau instansi pemerintah. Bahkan dalam persaingan di perguruan tinggi swasta yang semakin sengit fungsi Humas dapat memperkuat reputasi dan juga branding.

\section{Branding pada perguruan tinggi swasta}

Bila bicara branding maka erat hubungannya dengan reputasi yang dicapai organisasi tersebut. Tidak mudah bagi sebuah organisasi khususnya yang berorientasi pada profit untuk mewujudkan brand yang berbasis pada reputasi yang diakui masyarakat. Membangun dan mempertahankan reputasi adalah upaya yang terus menerus dilakukan oleh perusahaan. Untuk itu perlu diperjelas hubungan antara brand dan reputasi itu sendiri.

Pemahaman branding menurut Herwindo- seorang sarjana disain dan saat ini menjadi praktisi pada bisnis disain grafis- adalah segala hal yang membahas logo, corporate ID dan penerapannya (termasuk unsur warna, elemen grafis, dll), kekonsistenan penerapan sampai akhirnya persepsi masyarakat ketika melihat penerapan suatu identitas. Sedangkan branding menurut Levine (2003.13) is a complex process, but its goal is simple: it is the creation and development of a specific identity for a company, product, commodity, groups, or person.

Pendapat lain dikemukakan Prayudi dalam buku Strategic Public Relations (2016) yang menganggap erat hubungan brand dan reputasi. Prayudi (2016, h.197) mengutip Tom Duncan mendefinisikan brand sebagai sebuah persepsi yang dihasilkan dari sebuah pengalaman, atau informasi tentang sebuah perusahaan atau produk. Sementara itu Clifton dan Maughan mengutip interbrand- perusahaan konsultan brand terkemuka- dalam Prayudi (2016) menyatakan bahwa brand adalah gabungan atribut yang tangible dan intagible, disimbolisasikan dalam merek dagang (trademark), yang jika dikelola dengan baik, bisa menciptakan pengaruh dan memunculkan nilai”.

Dari pendapat-pendapat di atas dilihat bahwa branding merupakan sebuah upaya dalam mencipatakan sebuah persepsi di benak publik terhadap suatu brand (merek). Bila dikaitkan dengan perguruan tinggi swasta, tentu para praktisi humas di perguruan tinggi swasta punya pandangan mengenai branding.

Kepala Humas dan Dekan Fakultas Ilmu Komunikasi di Universitas Islam Sultan Agung (Unissula) Semarang Trimanah berpendapat bahwa branding adalah sebuah upaya untuk menciptakan reputasi. Dikatakannya: "upaya yang kita lakukan secara terus menerus dan konsisten supaya publik cepat mengenali perguruan tinggi kita meski mereka hanya melihat sekilas pada logo, warna, desain atau bahkan suara yang spesifik".

Sementara Gita juga beranggapan bahwa tujuan kampusnya melakukan branding adalah untuk mengelola merek institusi, karena dalam komponen-komponen merek tersebut terselip berbagai filosofi institusi yang membantu publik aware terhadap keberadaan suatu institusi.

Bila mengamati perguruan tinggi terkemuka di luar negeri khususnya di Amerika banyak namanama terkenal yang selalu mudah diingat. Sebut saja Harvard, UCLA, atau MIT. Perguruan tinggi 
tersebut selalu diasosiasikan sebagai institusi terbaik di dunia. Tentu yang menjadi faktor utama dari alasan orang mengenal perguruan tinggi tersebut adalah faktor reputasi.

Menurut Aruman dalam artikelnya di Majalah Mix Marketing Communications edisi 05/XIII/23 Mei-17 Juni 2016 mengenai “Building Global University Brand” bahwa Lembaga-lembaga publik yang mengandalkan dana dan kuliah dari pemerintah untuk pendapatan, sekarang mengalihkan promosinya melalui media sosial, pembelajaran online dan kredensial baru untuk memperkenalkan diri mereka ke siswa internasional. Menurutnya, disinilah pentingnya prestise dan reputasi. Aruman memberi gambaran bagaimana perguruan tinggi di Amerika membangun image mereka di luar negeri. Secara historis, universitas di AS mengandalkan pertukaran mahasiswa untuk membangun image mereka di luar negeri.

Namun saat ini banyak perguruan tinggi yang membangun cabangnya di luar negeri walau ada juga yang tidak berhasil. Hal ini mendorong sekolah untuk melihat metode yang lebih modern dalam membesarkan merek dari sekedar cara-cara konvensonal.

Oleh sebab itu menjadi hal mutlak yang mendasari sebuah perguruan tinggi untuk melakukan branding adalah memperkokoh reputasi. Reputasi merupakan aset non fisik organisasi yang jauh lebih besar dari aset fisik (Prayudi, 2016, h. 199). Perguruan tinggi swasta layaknya sebuah institusi pada umumnya juga merasa penting melakukan branding. Pakar Kehumasan Prayudi., Ph.D menganggap bila tidak ada upaya branding maka lama kelamaan perguruan tinggi tersebut akan ditinggalkan.

Asesor Profesi Kehumasan dan Dosen Komunikasi dari Universitas Atma Jaya Yogyakarta Setyo Budi berpendapat pentingnya produk yang dihasilkan bila ingin bicara tentang branding. Tidak sampai di situ, menurutnya memiliki produk saja tidaklah cukup. Produk yang dihasilkan pun harus memiliki kualitas yang teruji. Menurut Setyo, "Kalau tidak ada produk yang bagus sulit untuk melakukan branding".

Pada perguruan tinggi, pemahaman akan kualitas "produk" ujung tombaknya ada di program studi. Karena melalui program studi yang baik akan menciptakan produk yang baik pula sehingga branding yang dilakukan lebih mudah. Tentu di pihak internal perguruan tinggi sendiripun sudah mengetahui kekuatan program studi yang memiliki kualitas yang kompetitif. Ini akan memberi kekuatan sendiri dalam melakukan branding bahwa program studi yang ditawarkan kepada publik (calon mahasiswa) memang memiliki keunggulan dibanding kompetitor.

Begitu pula yang saat saat ini dilakukan oleh Humas KKGS melalui Kahumasnya mengatakan bahwa, Institusinya memosisikan diri sebagai salah satu sekolah (college) bisnis terkemuka di Indonesia dengan kekuatan pada kurikulum yang berbasis bisnis di seluruh program studi yang ada sebagai salah satu implementasinya. Pemosisian ini 'disuntikkan' pada seluruh aktivitas di Institusi, baik akademik maupun non akademik. Ini merupakan kekuatan yang ingin ditunjukkan kepada masyarakat sehingga Humas harus berupaya ke arah tersebut. 


\section{Dukungan humas dalam upaya branding}

Saat ini perguruan tinggi swasta gencar melakukan berbagai upaya untuk menarik mahasiswa baru. Usaha ini juga dilatarbelakangi karena semakin kompetitif nya persaingan antara perguruan tinggi swasta yang ada. Branding bisa jadi menjadi salah satu cara untuk menarik mahasiswa baru. Untuk itu perlu dilihat dulu kaitan humas dalam upaya branding dalam berbagai pandangan. Michael Lenvin (2003, h.16) mengatakan "The concept of branding and public relations are closelyinterwind. The job of Humas is to encourage the public to have positive thoughts about a particular company, products, service, or individual. Branding is the idea that particular set of attributes will encourage the public to have positive thoughts about a particular company, product, service, or individual. It's a subtle distinction but an essential one".

Disampaikan lagi oleh Lenvin, "Humas work behind the scenes, but its impact on branding is enormous... (h.17). Sementara itu dipertegas Prayudi (2016, h. 209) bahwa praktisi Humas membantu aspek "hubungan" dan mengembangkan pesan dalam bentuk program-program humas yang sejalan dengan strategi integreted marketing communications (IMC). Dalam bukunya Strategic Humas disebut bahwa untuk membangun brand relationship menjadi bagian yang tidak terpisahkan dari aktivitas yang dijalankan praktisi Humas.

Dari pendapat di atas jelas bahwa humas berperan dalam upaya branding. Branding bukan semata dilakukan dalam ranah marketing seperti yang selama ini dipahami. Tentu bagian yang dilakukan Humas dalam branding adalah usaha menumbuhkan kesadaran khalayak atau dalam bahasa Prayudi adalah membangun komunikasi mengenai brand perguruan tinggi kita.

Dalam The Public Relations and branding - The Ten Unavoidable Laws dari Devereux dan PeirsonSmith (2009, h. 69) salah satu yang harus dihindari dalam usaha branding oleh humas adalah "the brand is all (just don't tell everyone)". Menurutnya saat ini segala sesuatu dilakukan branding dan segala hal tentang tentang brand adalah membangun hubungan emosional dan rasional antara seluruh kekuatan customer dan brand. Aktivitas humas-dari publisitas ke promosiperkembangannya disesuaikan dengan persepsi ini- yaitu berdasarkan hubungan-hubungan yang terjalin.

Lisa Esti Puji Hartanti,- dalam kaitannya antara Humas dan branding - menyatakan bahwa humas harus mampu mengakomodir kebutuhan informasi khalayak. Perguruan tingginya berupaya membangun komunikasi dengan khalayak. Begitu pula pendapat dari Trimanah yang beranggapan bahwa komunikasi adalah tugas Humas dalam melakukan branding. Menurutnya tanpa adanya upaya untuk membranding perguruan tinggi swasta melalui berbagai kegiatan komunikasi, maka mustahil publik akan memiliki asosiasi tertentu di dalam benak dan persepsi mereka mengenai perguruan tinggi kita.

Sementara itu menurut Lisa, aktivitas menjadi level tertinggi dalam membangun brand. Disampaikannya yang biasa dilakukan kampusnya dalam membantu membangun persepsi adalah melalui kegiatan-kegiatan seperti memberikan pelatihan bagi siswa-siswa SMA, guru BK, kepala sekolah, dll, yang dilakukan oleh sumber daya yang ada di perguruan tingginya.

Survey yang dilakukan Majalah Mix Marketing Communications tahun 2015 (Aruman, edisi 05/XIII/23 Mei-17 Juni 2016) mengungkapkan bahwa banyak perguruan tinggi yang menerapkan 
strategi branding untuk meningkatkan kesadaran masyarakat terhadap merek perguruan tinggi bersangkutan. Cara yang dilakukan pun beraneka macam, diantaranya menyewa profesional pemasaran eksternal serta mengembangkan desain mobile untuk website termasuk mengoptimalkan pemanfaatan media sosial.

Perlu ada kerja sama antara PR dan marketing dalam mengedepankan brand perguruan tinggi. Menurut Prayudi, sinergitas antara marketing dan Humas menjadi krusial. ada aspek-aspek dimana pihak marketing memahami dunia konsumen yang semakin segmented. Di sinilah pentingnya komunikasi dua arah dan ini merupakan kegiatan yang harus dilakukan humas. Sayangnya menurutnya, justru banyak Humas officer yang belum aware pada aspek marketing karena masih banyak yang berfokus pada corporate communications.

Salah satu dalam 10 aturan melakukan branding disampaikan Tai dan Chew dalam Desmipian, Sulthan, dan Bestari S.R (jurnal Acta Diurna vol. 10 no.2 tahun 2014) adalah menggunakan hubungan masyarakat (Humas) untuk membangun merek. Hal ini mempertegas humas perguruan tinggi menjadi komponen penting untuk lebih berperan dalam membangun brand di institusinya.

Saat ini juga penting perguruan tinggi memikirkan sebuah komunikasi pemasaran yang terintegrasi (Integrated Marketing Communications). Pihak eksternal tidaklah pasif dalam mencari informasi. Sebagai contoh adalah konsumen yang tidak berhenti mencari informasi hanya dari web. Prayudi mengatakan bahwa konsumen membutuhkan informasi lebih dan di sinilah humas berperan karena perlu ada komunikasi yang bersifat dua arah. Devereux dan Peirson-Smith (2009, h. 69) menyatakan "The PR approach can use a variety of short and long-term, agenda, cost-effective and creative communication strategies to introduce and sustain the brand in the marketplace. In this way, customer understanding and brand devotion can be strategically developed with lasting results."

Terkait dengan membangun komunikasi dengan khalayak, menurut Lisa - dalam menghadapi era milenials, maka perlu juga mengakomodir kebutuhan informasi dari segmen tersebut. Apa yang dilakukan Unika Atma Jaya Jakarta adalah dengan cara membangun komunikasi melalui media sosial. Tentu juga selain itu, juga memanfaatkan media digital, seperti website, berita online, dan media jejaring seperti WA, dan Line.

Dari apa yang disampaikan Lisa, tampaklah bahwa membangun komunikasi dua arah juga harus disesuaikan dengan kebutuhan khalayak yang dituju. Artinya humas harus memberi berbagai opsi untuk dapat berkomunikasi dengan khalayak. Untuk dapat mengetahui kondisi khalayak, Humas Unissula melakukan brand disvovery melalui berbagai survey dan riset yang hasilnya kemudian menjadi tolok ukur dan dasar dalam membuat berbagai perencanaan dan program komunikasi.

Pakar dan konsultan branding Amalia Maulana mengatakan bahwa Branding tidak bisa lepas dari pemahaman tentang target audience dari brand tersebut. Juga mendapatkan umpan balik sejauh apa konsumen atau target audience sudah menjiwai pemahaman brand (Maulana, 2010).

Dua hal yang menjadi penekanan dari yang disampaikan Amalia Maulana adalah bahwa branding harus berorientasi pada khalayak yang menjadi target. Tentu dalam hal ini humas perguruan tinggi juga sudah mempunyai khalayak yang menjadi target. Khalayak yang sudah jelas karakternya akan menjadi penentu isi pesan yang akan disampaikan. Selain itu, penekanan kedua adalah perlu 
komunikasi dua arah agar institusi dapat mengetahui umpan balik dari khalayak. Umpan balik dapat terjadi bilamana humas secara aktif melakukan komunikasi dua arah dengan membuka berbagai saluran-saluran komunikasi.

Para humas perguruan tinggi swasta juga secara umum memandang perlu pentingnya komunikasi dua arah dan memahami khalayak perguruan tinggi masing-masing. Untuk komunikasi dua arah, humas perguruan tinggi sudah menyiapkan berbagai cara termasuk media sosial.

Seperti yang disampaikan Lenvine (2003) bahwa peran humas lebih bagaimana mengkomunikasikan brand menjadi dikenal khalayak. Hubungan antara perguruan tinggi dan khalayak harus tetap dijaga. Bahkan kepada calon mahasiswa saat masuh di SMA. Humas juga dapat berperan untuk menjaga komunikasi yang sudah terbangun. Menurut Prayudi, ibarat orang yang telah membeli produk, kita ingin orang tetap menggunakan produk kita. Dalam konteks pendidikan, mahasiswa dan lulusan dapat mempromosikan kampusnya kepada orang lain. Prayudi mengatakan; "kita sepakat bahwa jualan kita itu adalah jasa pendidikan so if we can service the student well.... saya bilang ke temen-temen bahwa sekali-sekali pemberitaan mengenai activity kegiatan di dalam harus disiarkan juga"

Semua ini hanya dapat terjadi bila perguruan tinggi memberikan pelayanan yang baik bagi mahasiswanya. Namun memang hambatan mengenai upaya humas ini datang dari internal perguruan tinggi sendiri termasuk dari pimpinan. Begitupula bagaimana humas dapat mensinergikan pekerjaannya dengan bagian marketing yang bisa saling tumpangtindih. Masalah ini dibenarkan Prayudi. Ia mengamati bahwa tantangan buat humas di perguruan tinggi adalah memberi pemahaman kepada pimpinan agar bisa menyatukan pola pikir marketing dan humas. Tentu termasuk kepada staf humasnya sendiri. Humas perlu terbuka pada setiap orang termasuk dengan bagian marketing agar dapat menemukan porsi kerja masing-masing.

Prayudi juga merasa perlu agar humas aktif memberitakan kegiatan-kegiatan di dalam kampus. Tujuannya agar kampus lebih dikenal oleh publik. Ini juga membantu membentuk brand perguruan tinggi.

\section{KESIMPULAN}

Branding pada perguruan tinggi swasta perlu dilakukan dalam rangka memperkuat reputasi. Reputasi harus dibentuk melalui kinerja yang baik. Humas berperan dalam upaya branding. Branding bukan semata dilakukan dalam ranah marketing seperti yang selama ini dipahami. Tentu bagian yang dilakukan humas dalam branding adalah membangun komunikasi mengenai brand perguruan tinggi.

Sinergi antara bagian humas dan marketing di perguruan tinggi swasta menjadi hal yang sangat penting untuk mendorong upaya branding. Oleh sebab itu pekerjaan marketing dan Humas harus saling terintegrasi. Perguruan tinggi swasta harus memberikan suatu diferensiasi (pembedaan) dan karakter sehingga masyarakat yang menjadi target menjadi tahu mengingat dan bisa memilih.

Humas perguruan tinggi -sebagai lembaga pendidikan- menjadi istimewa karena berada dalam institusi swasta yang tetap harus memikirkan profit sebagai modal keberlanjutan. Namun, di sisi lain humas berada dalam lembaga pendidikan yang diharapkan tidak sekedar mengejar sisi 
komersial sebagai tujuan utama. Humas pada perguruan tinggi memiliki ciri khusus dibandingkan pada institusi lainnya. Perbedaan ini dapat dilihat dari output yang dihasilkan. Humas perguruan tinggi-dalam membantu branding- mengedepankan capaian akademik dan non akademik sekaligus mengedepankan keunggulan yang dimiliki dibanding dengan program studi sejenis di kampus lain. Ujung tombaknya adalah pada kualitas program studi.

\section{Saran}

1.Harus ada pemahaman bersama dalam internal perguruan tinggi swasta dalam memahami pentingnya branding.

2.Humas harus diberikan peran yang jelas serta lebih luas dalam hal berkomunikasi dengan publik yang menjadi sasaran

3.Perlu dilakukan upaya terus menerus agar brand tetap "hidup" dalam benak dan persepsi publik.

\section{Ucapan Terima Kasih (Acknowledgement)}

Tulisan ini berdasarkan penelitian yang didanai Universitas Tarumanagara melalui Direktorat Penelitian dan Pengabdian Masyarakat. Atas dasar tersebut penulis mengucapkan penghargaan dan terima kasih yang sebesar-besarnya atas dukungannya. Juga penghargaan kepada seluruh narasumber yang telah memberi kontribusi sangat besar bagi penelitian ini.

\section{REFERENSI}

Aaker, D. A. (1991). Managing brand equity. New York, NY: Free Press.

Cutlip, S. M., Center, A. H., \& Broom, G. M. (2006). Effective public relations. UK: Pearson Prentice Hall.

Davereux, M. M. \& Peirson-Smith, A. (2009). Public relations in asia pacific communicating effectively across cultures. Wiley, John Wiley \& Sons (Asia) Pte.Ltd

Jefkins, F. \& Yadin, D. (1998). Public Relations. UK: Prentice Hall.

Lenvine, Michael (2003), A Branded word- adventures in humas and creations of superbrands. Hoboken, New Jersey: John Wiley \& Sons.

Lumbald, S. S. \& Stewart, G. K. (2005), Public relations for schools: A resource guide for principals. IAP Publishing.

Maulana, A. E. (2010, 8 Juni). Brand, branding dan peranannya bagi perusahaan. [Web log post]. Diunduh dari http://amaliamaulana.com/blog/brand-branding-dan-peranannya-bagiperusahaan/.

Mix Marketing Communications edisi 05/XIII/23 Mei-17 Juni 2016.

Morissan, M.A. (2008). Manajemen humas. Jakarta: Kencana.

Oliver, S. (2007). Public Relations Strategy (2nd. Ed). London: Kogan Page.

Prisgunanto, I. (2006). Komunikasi pemasaran: strategi dan taktik. Bogor: Ghalia Indonesia.

Poerwandari, E. K. (2001). Pendekatan kualitatif untuk penelitian perilaku manusia. Jakarta: Lembaga Pengembangan Sarana Pengukuran dan Pendidikan Psikologi (LPSP3) Universitas Indonesia.

Prayudi (2012). Humas stratejik. Komunikasi UPN Press.

Robbins, S. P. (1990). Organization theory: Structure, design, and applications. US: Prentice Hall.

Rangkuti, F. (2008). the power of brand, teknik mengelola brand equity dan strategi pengembangan merek. Jakarta: Gramedia.

Schiffman, L. G. \& Kanuk, L. L. (2000). Consumer behavior (5th. ed). New Jersey: Prentice Hall. 
Sutisna. (2003). Perilaku konsumen \& komunikasi pemasaran. Bandung: Remaja Rosdakarya. Sunarto (2012). Humas pemerintah dan komunikasi persuasif. Bandung: Alfabeta.

Susanto, A. B. \& Wijarnako, H. (2004). Power branding membangun merek unggul dan organisasi pendukungnya. Jakarta: Quantum Bisnis dan Manajemen.

http://scriptura.petra.ac.id/index.php/iko/article/view/16943/16929

http://komunikasi.unsoed.ac.id/sites/default/files/BRANDING\%20PERGURUAN\%20TINGGI\%20

NEGERI\%20(\%20Dindra\%20Desmipian,\%20M.Sulthan,\%20dan\%20Dian\%20Bestari\%20S.

R.\%20. 